\title{
The Relationship Between Mobile Phone Use, Metacognitive Awareness and Academic Achievement
}

\author{
Bulent Dos ${ }^{1}$ \\ ${ }^{1}$ Gaziantep University, Turkey \\ "E-mail: bulentdos@yahoo.com
}

\begin{abstract}
Mobile phones are getting smarter and the usage through university students becoming more popular. University students using mobile phones for talking, for texting message, for Internet search, for listening music, watching videos, playing games, using social media etc... Mobile phones are not accessory any more, they are integrated like our clothes. There are studies examining the effects of using mobile phones frequently. The aim of this study was to determine the relationship between mobile phone usage, satisfaction with life, academic achievement and metacognitive awareness. Metacognitive awareness inventory used to measure the awareness. Total GPA was used to measure the academic achievement and the mobile phone using time, the number of text messaging and callings are used for indicating the mobile phone usage. 250 total university students attended voluntarily to the study. The study carried out in private university in the southeast region of Turkey. The results indicated the usage of mobile phones are very frequent through university students. Many of the students are using mobile phones heavily. There was a positive relationship between mobile phone usage and academic achievement, also between mobile phone usage and metacognitive awareness.
\end{abstract}

Keywords: mobile phone use, metacognitive awareness, academic achievement

\section{Introduction}

What would you call a device that has a screen, a keyboard, storage for personal information such as contacts, email, documents, the ability to play audio and video files, some games, a spreadsheet program, and a communications capability? says Greenspun (2005) in his article. Today mobile phones allow users to call, text, email, video conference, micro blog, interact on social-networks, surf the Internet, watch and share videos and pictures, play video games and utilize a tremendous array of software driven applications (Lepp, Barkley and Karpinski, 2014). Mobile phones allow users to do all that applications and activities anytime and anywhere in contrast to personal computers. Advances in digital technology reduced the distinction between mobile phones and traditional notions of the computer. Mobile phones can be accepted as computers in terms of their functioning capability (Lepp, Barkley and Karpinski, 2014; Lepp, Barkley, Sanders, Rebold and Gates, 2013). According to TSI (Turkish Statistical Institute, 2014) the number of mobile phone subscriber number is 70.791 .075 in 2014 where the number in 1994 is 81,276 . In twenty years mobile phone usage is increased exponentially in Turkey and in other countries (Jackson, von Eye, Fitzgerald, Witt and Zhao, 2011). In 2011, the number of mobile phones world-wide exceeds 5.6 billion, showing an $11 \%$ increase compared to its previous year and an average penetration rate of $79.86 \%$ worldwide (Gartner, 2011). Mobile phone usage (MPUse) has an in- 
fluence on changing the attitudes, values, beliefs and behaviors of the people. University students are using mobile phones as a part of their life. One student from this study stated: I can't live without my mobile phone because now it is a part of my body! As MPUse is becoming and indispensable part of people's lives, it is also becoming source of severe problems for both individuals and organizations (Salehan and Negahban, 2013). A study on MPUse and happiness and academic performance showed that "for the population studied, high frequency cell phone users tended to have lower GPA, higher anxiety, and lower satisfaction with life (SWL) relative to their peers who used the cell phone less often" (Lepp, Barkley and Karpinski, 2014). One of the strong predictor of academic success is metacognition (Dunning, Johnson, Ehrlinger and Kruger, 2003; Kruger and Dunning, 1999). It refers to higherorder mental processes involved in learning such as making plans for learning, using appropriate skills and strategies to solve a problem, making estimates of performance, and calibrating the extent of learning (Dunslosky and Thiede, 1998). Considering all this factors on academic achievement the purpose of this study was to investigate the potential relationships: MPUse and academic achievement; MPUse and Metacognitive awareness; and MPUse and happiness.

\section{Review of related work}

Bringing mobile phones to the school and using it while studying or listening to the teacher is a common behavior for university students (Junco and Cotton, 2011; Jacobsen and Forste, 2012). Students are using their mobile phones for sending or receiving text messages, communicating on Facebook or surfing in Internet while they are in class. Likewise, Sánchez-Martínez and Otero (2009) found that although CPUse was typically prohibited in the classroom, half of the students in their sample reported bringing the device to school and keeping it on during class. Using mobile phones interfere with school work and consequently revealing school failure (Wood, Zivcakova, Gentile, Archer, De Pasquale and Nosko, 2012). Jacobsen and Forste (2011) identified a negative relationship between the use of a variety of electronic media including cell phones (calling and texting) and academic performance (selfreported GPA) among first year university students in the United States. End, Worthman, Mathews and Wetterau (2009) found that ringing cell phone impairs the learning performance. Participants in the ringing condition performed significantly worse on the disrupted test items and were less likely to include the disrupted information in their notes. In recent study Walsh, Fielder, Carey and Carey (2013) found negative association between media use and academic outcomes after controlling for prior academics and demographics among first year female college students. Sánchez-Martínez and Otero (2009) found a relationship between "intensive" CPUse and school failure. Lee (2014) using a sample of African American and Hispanic middle and high school teenagers found a negative relationship between Facebook activity and math grades.

Psychologist Ed Diener (2008), author of Happiness: Unlocking the Mysteries of Psychological Wealth, describes what psychologists call "subjective well-being" as a combination of life satisfaction and having more positive emotions than negative emotions. One can see that many people seem entertaining and satisfied when they are using their mobile phones. Very little research has been conducted to explore the relationship between happiness and mobile phone use. Lepp et al, (2014) studied this relationship and found that high frequency mobile phone users tended to have lower academic performance, higher anxiety and lower satisfaction with life relative to their peers who used the mobile phone less often. Life satisfaction are influenced by success or failure in important life domains such as academic performance for university students (Pavot and Diener, 2008). 


\section{Mobile phone use, metacognitive awareness and satisfaction with life}

Metacognitive awareness is very important for its effect on academic achievement. Metacognition is important in learning and is a strong predictor of academic success (Dunning, Johnson, Ehrlinger and Kruger, 2003; Kruger and Dunning, 1999). Metacognition refers to awareness and monitoring of one's thoughts and task performance, or more simply, thinking about your thinking (Flavell, 1979).

College students and adolescents use electronic media simultaneously with other media or during activities requiring more focused attention, like class (Jacobsen and Forste, 2011). Multi-tasking is the apparent performance by an individual of handling more than one task at the same time. Multitasking is divided attention and non-sequential task switching for ill defined tasks (Junco and Cotten, 2012). Many researches indicated multi-tasking is the cause of negative relationship between MPUse and academic performance (Wood et al., 2012; Junco and Cotton, 2012; Rosen, Carrier and Cheever, 2013).

Mayer and Moreno's (2003) research-based cognitive theory of learning and information overload provides a framework to understand how multi-tasking can affect the learning process. There are four assumptions based on the evidence of how we process information: 1. That the human information processing system has two channels auditory and verbal; 2 . That each channel has a limited capacity for cognitive processing; 3 . This capacity is used when selecting and then modulating (how the selected item is processed) presented stimuli; and 4. Meaningful learning requires that a substantial amount of cognitive processing occur either in the visual or auditory channels (Chun et al., 2011; Mayer \& Moreno, 2003). Multi-tasking is preventing one to develop higher order thinking skillls such as metacognitive skills.

Life satisfaction, as first described by Shin and Johnson (1978), "refers to a judgmental process in which individuals assess the quality of their lives on the basis of their own unique set of criteria" (Pavot \& Diener, 1993: 164). The most widely used measure of life satisfaction is the "Satisfaction with Life Scale" developed by Diener, Emmons, Larsen, and Griffin (1985). Since its introduction, it has been used in hundreds of studies and a variety of clinical settings. Yetim (1993) adaptated this scale into Turkish and Doğan and Totan (2013) validated finally this scale into Turkish. According to Lepp, Barkley and Karpinski (2014) MPUse increases subjective well-being or happiness. High GPA is also can be considered to increase the happiness. For university students, an important life domain influential in judgments of life satisfaction is academic performance (Pavot \& Diener, 2008; Schimmack, Diener, \& Oishi, 2002).

\section{Research Questions and hypotheses}

Considering the literature we can assume that there is a relation between MPUse, academic performance and satisfaction with life. Lepp et al, (2014) found relationship MPUse and academic performance and satisfaction with life. The main features of current smart mobile phones provide students to search real time in the net, communicate with teachers and students whenever they want. Therefore two main research questions were: (1) What is the relationship between total mobile phone use (MPUse), Academic Performance (actual GPA), Metacognitive Awareness (MCA) and Satisfaction with Life (SWL) (2) What is the relationship between Texting, Academic Performance (actual GPA), Metacognitive Awareness (MCA), and Satisfaction with Life (SWL) The following hypotheses were investigated:

- $\quad$ (RQ $1-\mathrm{H} 1)$. MPUse will have a negative relationship with GPA and MCA and SWL

- $\quad($ RQ 2 - H1). Texting will have a negative relationship with GPA and MCA and SWL 


\section{Methodology}

\section{Participants and Procedures}

The sample of this study group consists of 176 female and 33 male students, totally 209 students from a mid-size university located at the south-east region of Turkey. Students were all studying at the faculty of education, $\% 23,4$ of the students from primary school education, $\% 16,3$ of the students from mathematics education, \%16,7 of the students from English Teaching education, \%13,4 of the students from pyschlogical counselling education and finally 30,1 of the students from pre-school education . $\% 32,5$ of the students studying their first year, \%42,6 of the students studying their second year, \% 9,1 of the students studying their third year and \% 15,8 of the students studying their fourth year of their education. The ages of the students varies between 18 and 26. The average age of participants is 21.2. The printed questionnaires were adminstered to the students in the spring term of 2014. The GPA in this study was self reported.

\section{Measures}

The survey includes five separate sections: (1) demographic information, (2) questions about mobile phone and texting use (Lepp, et al., 2014), (3) satisfaction with life (Doğan and Totan, 2013), (4) Self reported GPA, (5) metacognitive awareness inventory (Akın, Abacı \& Çetin, 2007).

Demographic information included gender, age, department and year at the school. Questions about mobile phone usage were asked to the students that the total MPUse in a day in minutes. Students were asked to make their best prediction about the total MPUse except for listening music. Also students were asked how many message totally they received or sent including SMS, Viber, WhatsApp and other applications. Two texting (sending and receiving) highly correlated (Pearson correlation= .866) Daily calling logs also asked to students. The SWL inventory includes six questions about general life satisfaction using a 4-point Likert scale from never (coded 0) to frequently (coded 3). Higher scores on this measure indicate more life satisfaction, with a score of 12 representing the neutral point on the scale. Previous research demonstrates the SWL has strong internal consistency (Coefficient Alpha $=.87$ ) (Lepp et al., 2014). Likewise the SWL performed well with this study's sample of undergraduate students (Coefficient Alpha $=.81, \mathrm{~N}=209$ ). Students were asked to write their total GPA, first year students were asked to write the first term GPA.

The metacognitive awareness inventory includes eight subscales: (1) declarative knowledge (8 item), (2) procedural knowledge (4 item), (3) conditional knowledge (5 item), (4) planning (7 item), (5) information management strategies (9 item), (6) monitoring (8 item), (7) debugging strategies (5 item) and (8) evaluation (6 item). The coefficient alpha is calculated in this study is .93, $\mathrm{N}=209$ ).

The questionnaire was firstly administered to a class (28 students) and get feedback about the clearance, meaning and the language of understanding. The questionnaire was altered according to the suggestions.

\section{Data analysis}

Descriptive statistics used for demographic variables with SPSS 17 software. Additionally, Pearson correlations between main variables were examined prior to the regression analysis. 


\section{Results}

\section{Descriptive statistics and correlations}

Before conducting any descriptive or inferential statistics, an examination of outliers $(\mathrm{z} \pm 2.58)$ on the major variables (i.e., CPUse, Texting, GPA, and SWL) was conducted. Descriptive statistics for major variables are presented in Table 1.

Table 1. Descriptive statistics for major variables

\begin{tabular}{|l|l|r|r|r|r|}
\hline \multicolumn{7}{|c|}{ Descriptive Statistics } \\
\hline & \multicolumn{1}{|c|}{$\mathrm{N}$} & Minimum & Maximum & \multicolumn{1}{c|}{ Mean } & Std. Deviation \\
\hline MPUse & 209 & 3,00 & 960,00 & 319,60 & 204,86 \\
\hline Sent messages & 209 & 10,00 & 800,00 & 115,05 & 140,00 \\
\hline Total texting & 209 & 10,00 & 1000,00 & 138,87 & 183,65 \\
\hline Outgoing calls & 209 & 10,00 & 150 & 8,97 & 14,045 \\
\hline Incoming calls & 209 & 10,00 & 50,00 & 9,40 & 9,14 \\
\hline SWL & 209 & 1,00 & 18,00 & 11,28 & 4,05 \\
\hline MCA & 209 & 2,06 & 4,86 & 3,49 &, 51 \\
\hline
\end{tabular}

MPUse $=$ Total Mobile Phone Use

SWL $=$ Satisfaction With Life

$\mathrm{MCA}=$ Metacognitive Awareness

Students reported spending average 319,60 ( $\mathrm{SD}=150,86)$ minutes per day using their mobile phones, and sending average $115(\mathrm{SD}=65)$ messages per day while receiving $138(\mathrm{SD}=72)$ messages per day. Mean GPA of the students were 2,91 ( $\mathrm{SD}=, 53)$. Additionally satisfaction with life score shows that students have neutral happiness levels (Mean=11,2 $\mathrm{SD}=4,05$ ). Students have high metacognitive awareness scores (Mean=3,49 $\mathrm{SD}=, 51)$.

Table 2. Pearson correlations between the variables for research question $(\mathrm{N}=209)$

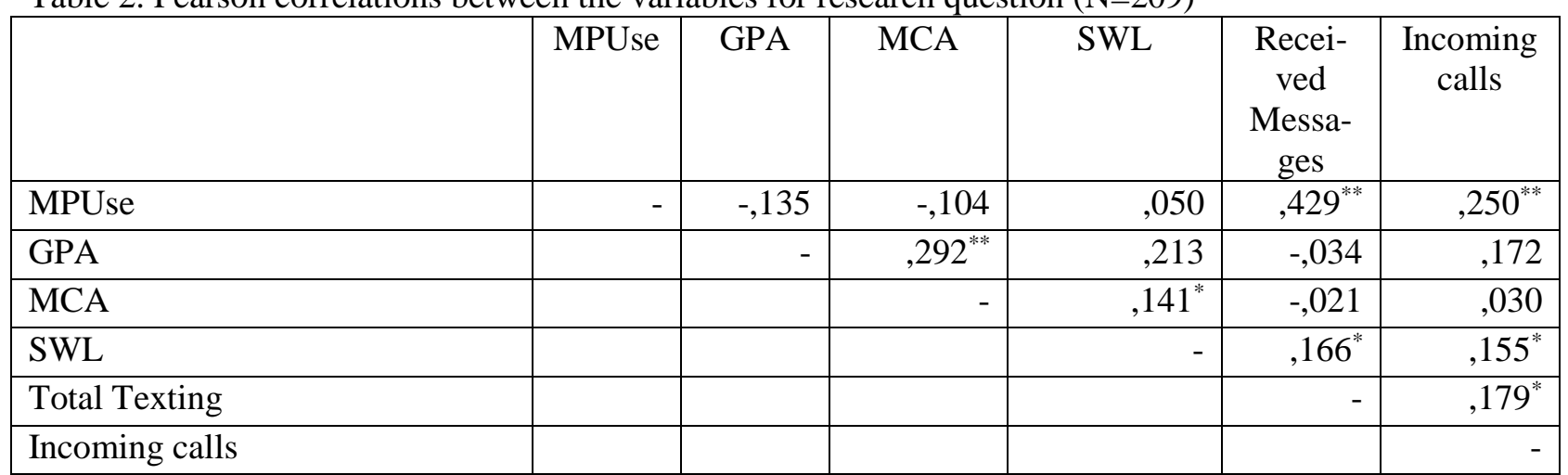

**. Correlation is significant at the 0.01 level

*. Correlation is significant at the 0.05 level 
Table 2 include the zero-order Pearson correlations between the variables for the two data sets (i.e., MPUse, Texting, SWL, MCA). The hypothesized correlations between the major variables were not in the expected direction and not statistically significant $(\mathrm{p}<.05)$. The correlations between MPUse and SWL, MCA and GPA were not statistically significant ( $p>.05$ ). Also the correlations between Texting and SWL, MCA and GPA were not statistically significant ( $\mathrm{p}>$.05). But apart from research hypotheses there was a correlation between GPA and MCA, MCA and SWL, SWL and received messages. Because of the correlation between unexpected variables, regression analysis was done between newly correlated variables. The first analysis was done between MCA and GPA. Table 3 shows the effect of the MCA on the GPA with the analysis of regression.

Table 3. The effect of MCA on GPA (Linear regression analysis)

\begin{tabular}{|l|l|l|l|l|l|l|l|}
\hline Model 1 & \multicolumn{5}{l}{ Predicted variable: GPA } & \\
\hline Variables & $\mathrm{B}$ & StError & Beta & $\mathrm{t}$ & $\mathrm{p}$ & Zero-order & Partial \\
\hline Constant & 2,802 &, 297 & & 9,44 &, 000 & & \\
\hline MCA &, 268 &, 100 &, 292 & 2,67 &, 009 &, 292 &, 292 \\
\hline $\mathrm{R}=, 292 \mathbf{R}^{2}=, 085$ & $\mathrm{~F}(1,209)=7,15 \mathrm{p}=0,009$ \\
\hline
\end{tabular}

Linear regression analysis was done to find out the effect of the MCA on GPA. Table 3 shows that MCA has a statistically significant effect on GPA. This model explains the $\% 8$ of variance of GPA of university students $(\mathrm{F}(1,209)=7,15 \mathrm{p}=0,009)$. The second regression analysis was done between MCA and SWL. Table 4 shows the effect of the MCA on SWL.

Table 4. The effect of MCA on SWL (Linear regression analysis)

\begin{tabular}{|l|l|l|l|l|l|l|l|}
\hline Model 1 & \multicolumn{5}{l|}{ Predicted variable: SWL } & \\
\hline Variables & B & StError & Beta & t & $\mathrm{p}$ & Zero-order & Partial \\
\hline Constant & 7,42 & 1,92 & & 3,86 &, 000 & & \\
\hline MCA & 1,10 &, 54 &, 14 & 2,03 &, 043 &, 141 &, 141 \\
\hline R=,141 $R^{2}=, 020$ & & & & & \\
\hline
\end{tabular}

Linear regression analysis was done to find out the effect of the MCA on SWL. Table 4 shows that MCA has a statistically significant effect on SWL. This model explains the $\% 2$ of variance of SWL of university students $(\mathrm{F}(1,209)=4,15 \mathrm{p}=0,43)$. The third regression analysis was done between received message and SWL. Table 5 shows the effect of the received message on SWL. 
Table 5. The effect of Received message on SWL (Linear regression analysis)

\begin{tabular}{|c|c|c|c|c|c|c|c|}
\hline Model 1 & Predic & d variab & SWL & & & & \\
\hline Variables & B & StError & Beta & $\mathrm{t}$ & $\mathrm{p}$ & Zero-order & Partial \\
\hline Constant & 10,83 & ,34 & & 31,38 & ,000 & & \\
\hline $\begin{array}{l}\text { Received } \\
\text { message }\end{array}$ & ,004 & ,00 & ,16 & 2,39 & ,018 & 166, & 166, \\
\hline \multicolumn{8}{|c|}{$\mathrm{R}=, 166 \boldsymbol{R}^{2}=, 027 \quad \mathrm{~F}(1,209)=5,72 \quad \mathrm{p}=0,018$} \\
\hline
\end{tabular}

Linear regression analysis was done to find out the effect of the total received message on SWL. Table 5 shows that total received message has a statistically significant effect on SWL. This model explains about the $\% 3$ of variance of SWL of university students $(F(1,209)=5,72 p=0,018)$.

\section{Discussion}

The purpose of this study was to examine the influence of two measures of MPUse (Total MPUse and Texting) on Academic Performance (GPA), SWL, and in turn, Metacognitive Awareness (MCA) The results indicated that two measures of MPUse and texting is not related with MCA and GPA. The MPUsers divided into three groups (high frequency, normal and lower users) according to the literature (Lepp et al., 2014). There is also no relation found between these three groups between MCA, SWL and GPA. GPA was self-reported in this study, the explanation can be made why there is no relationship between GPA and MPUse. The researcher couldn't get the GPA scores of the students because of the ethical considerations. Previous researches indicate that there is a negative relation between MPUse and GPA (Lepp et al., 2014; Jacobsen \& Forste, 2011; Junco \& Cotton, 2011, 2012; Rosen, Carrier et al., 2013; Wood et al., 2012). Because the average satisfaction scores of the students is at neutral level, we can say this might resulted that there is no relationship found between SWL and MPUse. Lepp et al, (2014) found a mediated relationship between MPUse and subjective well-being (happiness) as measured by the Satisfaction with Life Scale (SWL; Diener et al., 1985). Previous research has showed that the SWL is predictive of various life outcomes including physical and mental health, longevity, marital satisfaction, stronger social relationships, reduced risk of suicide, and alcohol and chemical abuse (Pavot \& Diener, 1993, 2008). MPUse is also related with physical activity (Lepp et al., 2013) that MPUse lowers the physical activity and this results some healthy problems leading unhappiness.

This study revealed some of implications beyond its research hypotheses. The first finding about this is the effect of MCA on total GPA. That means MCA can predict the $\% 8$ of the variance of total GPA of the university students. Previous research shows that MCA has an effect on the total GPA (Bagceci, Döş and Sarıca, 2011; Tok, Ozgan and Döş, 2010). Tok et al., (2010) found that MCA can predict the $\% 6$ of the academic achievement of university students. The result of this study is consisting with the previous study in its prediction of academic achievement.

The second unexpected result of this study was the effect of MCA on SWL. MCA has a positive effect on SWL and can predict \%2 of its variance. SWL should be related with GPA but in this study SWL was related with MCA and total received message. Previous re-search has demonstrated that the SWLS is predictive of various life outcomes including physical and mental health, longevity, marital 
satisfaction, stronger social relationships, reduced risk of suicide, and alcohol and chemical abuse (Pavot \& Diener, 1993, 2008). Also SWL is positively related with GPA and negatively related with anxiety (Lepp et al, 2014). Someone can think that MCA leads high GPA and high GPA leads SWL. But when we control the GPA there is no statistically significance between MCA and SWL.

The third finding of this study was the relation between received message and SWL. The regression analysis show that total received message can predict about the \% 3 of the variance of the SWL. Lepp et al., (2014) found no statistically relationship between texting and SWL. They also found negative relation with GPA and positive relation with anxiety.

University students are using their mobile phones even at their classrooms. The main aim of this study was to explore the effect of mobile phone usage on the happiness, academic achievement and metacognitive awareness. But there was no statistically significant result between mobile phone usage and happiness, academic achievement and metacognitive awareness. This may be because mobile phones are now devices we use in our daily lives. We got used to live with these devices and not effecting our academic achievements. But this usage may lower another behavior of us such as communication and interaction capabilities, higher order thinking skills. The future studies can study this kind of relations. This study showed also that metacognitive awareness is very important for academic achievement and satisfaction with life. This study could be done in different settings with different scales or variables.

\section{REFERENCES}

Akın, A., Abac1, R., \& Çetin, B. (2007). The validity and reliability of the Turkish version of the metacognitive awareness inventory, Educational Sciences: Theory \& Practice, 7(2), 671-678

Bağçeci, B., Döş, B. \& Sarıca, R. (2011). İlköğretim Öğrencilerinin Üstbilişsel Farkındalık Düzeyleri İle Akademik Başarısı Arasındaki İlişkinin İncelenmesi, Mustafa Kemal Üniversitesi Sosyal Bilimler Enstitüsü Dergisi, 8 (16), s.551-566

Chun, M. M., Golomb, J. D., \& Turk-Browne, N. B. (2011). A taxonomy of external and internal attention. Annual Review of Psychology, 62,73-101

Diener, E., Emmons, R., Larsen, J., \& Griffin, S. (1985). The Satisfaction with Life Scale. Personality Assessment, 49(1), 71-75.

Diener, E. (2008). Happiness: Unlocking the Mysteries of Psychological Wealth, Wiley-Blackwell

Doğan, T. \& Totan, T. (2013). Psychometric properties of Turkish version of the Subjective Happiness Scale, The Journal of Happiness \& Well-Being 2013, 1(1)

Dunning, D., Johnson, K., Ehrlinger, J., and Kruger, J. (2003) Why people fail to recognize their own incompetence. Current Directions in Psychological Science 12, 3, 83-87.

End, C. M., Worthman, S., Mathews, M. B. and Watterau, K. (2009). Costly Cell Phones: The Impact of Cell Phone Rings on Academic Performance, Teaching of Psychology Vol. 37, Iss. 1, 2009

Flavell, J.H.(1979). Metacognition and cognitive monitoring: A new area of cognitive-developmental inquiry. American Psychologist, 34, 906-911

Greenspun, P (2005). Mobile Phone As Home Computer http://philip.greenspun.com/business/mobilephone-as-home-computer

Jacobsen, W. C., \& Forste, R. (2011). The wired generation: Academic and social outcomes of electronic media use among university students. Cyberpsychology, Behavior, and Social Networking, 14(5), 275-280

Jackson, L. A., von Eye, A., Fitzgerald, H. E., Witt, E. A., \& Zhao, Y. (2011). Internet use, videogame playing and cell phone use as predictors of children's body mass index (BMI), body weight, academic performance, and social and overall self-esteem. Computers in Human Behavior, 27, 599-604 
Junco, R., \& Cotten, S. R. (2011). Perceived academic effects of instant messaging use. Computers \& Education, 56(2), 370-378.

Kruger, J., and Dunning, D. (1999) Unskilled and unaware of it: How differences in recognizing one's own incompetence lead to inflated self-assessments. Journal of Personality and Social Psycho$\operatorname{logy} 77,6,1121-1134$.

Lee, E. B. (2014). Facebook Use and Texting Among African American and Hispanic Teenagers An Implication for Academic Performance, Journal of Black Studies, March 2014 vol. 45 no. 2 83101

Lepp, A., Barkley, J. E., Sanders, G. J., Rebold, M., \& Gates, P. (2013). The relationship between cell phone use, physical and sedentary activity, and cardiorespiratory fitness in a sample of US college students. International Journal of Behavioral Nutrition and Physical Activity, 10, 79

Lepp, A., Barkley, J. E. \& Karpinski, A.C. (2014). The relationship between cell phone use, academic performance, anxiety, and Satisfaction with Life in college students, Computers in Human Behavior 31 (2014) 343-350

Mayer, R.E. \& Moreno, R. (2003). Nine Ways to Reduce Cognitive Load in Multimedia Learning, Educational Psychologist, 38(1), 43-52

Pavot, W., \& Diener, E. (1993). Review of the Satisfaction with Life Scale. Psychological Assessment, $5(2), 164-172$

Pavot, W., \& Diener, E. (2008). The Satisfaction with Life Scale and the emerging construct of life satisfaction. The Journal of Positive Psychology, 3(2), 137-152

Rosen, L. D., Carrier, M., \& Cheever, N. A. (2013). Facebook and texting made me do it: Mediainduced task-switching while studying. Computers in Human Behavior, 29, 948-958

Salehan, M. \& Negahban, A. (2013). Social networking on smartphones: When mobile phones become addictive, Computers in Human Behavior 29 (2013) 2632-2639

Sánchez-Martínez, M., \& Otero, A. (2009). Factors associated with cell phone use in adolescents in the community of Madrid (Spain).Cyber Psychology \& Behavior, 12, 131-137.

Schimmack, U., Diener, E., \& Oishi, S. (2002). Life-satisfaction is a momentary judgment and a stable personality characteristic: The use of chronically accessible and stable sources. Journal of Personality, 70, 345-384.

Shin, D. C., \& Johnson, D. M. (1978). Avowed happiness as an overall assessment of the quality of life. Social Indicators Research, 5, 475-492

Tok. H. ,Özgan. H., Döş, B. (2010). Assessing Metacognitve Awareness and Learning Strategies as Positive Predictors for Success in a Distance Learning Class, Mustafa Kemal Üniversitesi Sosyal Bilimler Enstitüsü Dergisi, Cilt/Volume: 7 Say1/Issue: 14, s. 127 - 137.

Walsh, J. L., Fielder, R. L., Carey, K.B. \& Carey, M.P. (2013). Female College Students' Media Use and Academic Outcomes Results From a Longitudinal Cohort Study, Emerging Adulthood, September 2013 vol. 1 no. 3 219-232

Wood, E., Zivcakova, L., Gentile, P., Archer, K., De Pasquale, D., \& Nosko, A. (2012). Examining the impact of off-task multi-tasking with technology on real-time classroom learning. Computers \& Education, 58, 365-374

Yetim, Ü. (1993). Kişisel projelerin organizasyonu ve örüntüsü açısından yaşam doyumu. [In Turkish: The pattern of organization and life satisfaction in terms of personal projects]. Unpublished doctorate dissertation. Ege University, Institute of Social Science, İzmir. 